(Paper No. 2493.)

\title{
"The Carrara-Marble District Railway."
}

By Charles Preller Sheibner, Ph.D., Assoc. M. Inst. C.E.

This railway was completed in May 1890, and owing to the peculiar nature alike of its alignment and of its traffic, presents. several striking features. The Carrara district is situated between Spezzia and Leghorn on the Mediterranean!seaboard, on which it has four shipping-places provided with large storeyards, wharves, piers, and cranes. In addition to these facilities for the export of the marble, the Mediterranean trunk railway which skirts the coast, has, within a distance of abont 20 miles, six stations and extensive storeyards. The principal towns are Carrara, Massa, Seravezza, Pietrasanta, Camajore, and Viareggio, which, including the villages of the neighbourhood, contain in the aggregate, upwards of 160,000 inhabitants over an areal of about 200 square miles; so that, as regards density of population, the district compares with several of the populous mining-districts of England and Wales.

\section{Geological Features.}

The range called the Apuan Alps, more commonly known as the Carrara mountains, is an offshoot of the Apennines trending from N.N.W. to S.S.E., and consists of a series of sharply-defined peaks, the highest of which, in the centre of the chain, rises to about 6,000 feet above sea-level, the whole range presenting in its outline the form of an elliptic dome. Early geologists held that the extensive amygdaloidal beds of marble, which rest on paleozoio schists, were of igneous origin; but organic remains, discovered in the series of stratified and sharply-twisted anticlinal folds characteristic of the range, have led to the conclusion that the marble of the Carrara district is triassic limestone whose present saccaroidal or crystalline state is due to lateral and superincumbent pressure under high temperature. The stratigraphical structure of the range is as follows:- 


\begin{tabular}{|c|c|}
\hline $\begin{array}{l}\text { Paleozoic (permian) schists, about } . .4 . \\
\text { Semi-crystalline (lower trias) limestone, called "Grezzoni" } \\
\text { Saccaroidal limestone (trias) or marble strats } \\
\text { Semi-crystalline (upper trias) limestone, called "Cipollini" }\end{array}$ & $\begin{array}{c}\text { Feet. } \\
4,000 \\
1,500 \\
3,500 \\
2,000\end{array}$ \\
\hline & 11,000 \\
\hline
\end{tabular}

It is thus seen that the marble strata proper, which cover an area of about 80 square miles, and yield besides the pure white marble, the grey (bardiglio), the veined (fiorito), and the manycoloured (breccia) varieties, reach in places to the enormous depth, measured vertically, of $\frac{3}{4}$ mile, as is shown by the outcrops, by the terraced quarries, and by the sections recently laid open in the cuttings and tunnels of the railway. The supply of marble for ornamental and building purposes of all descriptions is therefore practically inexhaustible.

\section{WOREING OF THE QUARRIES.}

The marble district is divided into three sections called the Carrara, Massa, and Seravezza divisions, from the three parallel valleys so named which run at right-angles to the crest of the range towards the seaboard, Fig. 1, Plate 11. All the quarriessome of which were worked by the Romans as early as 200 B.c., as is attested by inscriptions discovered on the spot-are surfaceworkings at an altitude of from 700 feet to 2,000 feet, and in some cases, e.g., the Monte Altissimo quarries in the Seravezza division, which yield the finest statuary marble of the whole district, 3,000 feet above sea-level. They are situated for the most part in the deep gulleys of the range, and the marble debris produced in the blasting and dressing operations is thrown down the mountain sides, where it has accumulated for centuries in immense quantities, and is a fruitful source not only of inconvenience and litigation but frequently of danger. The blocks of marble, which average 10 tons, weigh sometimes as much as 40 tons and contain 500 cubic feet, the weight of Carrara marble being 2.8 metric tons per cubic metre $=0.081$ English ton per cubic foot. They are let down from the quarries on rough inclined planes by means of runners, cross-beams, and ropes twisted round equidistant fixed poles, Fig. 3, Plate 11, to the loading-stages of the railway, or of the bullock carts, whence they are conveyed either to the saw-mills situated in the lower valleys, or to the storeyards at the railway 
stations and shipping places. Various experiments have been made from time to time, with a view of substituting mechanical contrivances for this slow and often dangerous process of sliding the blocks down; but the multiplicity of these inclines scattered over a large number of quarries, no less than the high motiveand brake-power required for such heavy loads on gradients varying from 10 to 50 per cent., and the consequently excessive outlay that would be required for the introduction of these methods, have hitherto greatly militated against their adoption. The Author has recently proposed an effectual and comparatively inexpensive appliance for this purpose, to which reference will be made hereafter.

The annual output of the quarries in the three divisions averages about 150,000 tons at Carrara, 20,000 tons at Massa, and 35,000 tons at Seravezza; it should, however, be added that the various operations of sawing and working the marble often produce a double, and in some cases treble local traffic.

\section{Saw-Mills and Polishing Works.}

The number of saw-mills is seventy-five in the Carrara, thirty in the Massa, and forty-five in the Seravezza division, with three hundred and thirty-five, one hundred and fifty, and two hundred saw-frames respectively, making a total of six hundred and eighty-five saw-frames. These mills, most of which are driven by water, some by gas-engines and some by steam, work, as a rule, day and night throughout the year. The saw-frames are constructed for blocks up to 10 tons or about 125 cubic feet; they require each about $4 \mathrm{HP}$, and consume 100 tons of sharp sand in cutting from 150 to 200 tons of marble into slabs whose thickness varies according to the number of saw-plates. The total waterpower used in the district for this purpose is about 3,000 HP., and the total output of sawn slabs amounts to upwards of 100,000 tons per annum. Irrespective of the saw-mills, there are about one hundred and thirty polishing works for ornamental and building purposes generally. At first sight, the district would seem to offer a remunerative field for the introduction of electric motivepower; but the water-power is obtained so cheaply, the royalty paid to the State for its use being at the rate of $4 s$. per HP. per annum, that under existing conditions, electricity could not compete with it. 


\section{Viareggio Sand Excavations.}

The sharp, heavy, white, and almost purely siliceous sand used in the sawing of marble is obtained exclusively from extensive subaqueous beds near Viareggio, Fig. 1, Plate 11. These deposits, formed by the disintegration of the hard sandstone (macigno) strata which now bound the northern banks of the lake of Massacciucoli, near Viareggio, and at one time extended to the seashore, cover a superficial area of upwards of 1,600 acres, and are about 42 feet in depth; thus representing an available supply of over 100 million cubic yards, or 105 million tons (the specific gravity being $1 \cdot 4$. The sand is got by manual labour, with long spoons, about 230 tons per day or 70,000 tons per annum being excavated to the full depth of the deposits. It is then taken in barges (by canal) to the Viareggio wharves, a distance of less than 2 miles, where it is unloaded, and conveyed chiefly by rail, but to some extent by bullock-carts and also by sea, to Seravezza, Massa, and Carrara. Here, too, as in many similar cases in Italy, the cheapness and abundance of labour, the high cost of coal, and the fact of the operations being carried on simultaneously in no fewer than ten pits instead of being concentrated at one point, militate against substituting mechanical for manual labour.

The dredging is at present performed by forty-two men, who take fourteen empty barges (about 17 tons capacity each), with dredging apparatus on separate boats, from Viareggio up to the pits in one hour, raise about 240 tons of sand in three and a half hours, returning with the loaded barges down to Viareggio in one hour, and unloading the sand at the wharves in two and a half hours, making a total of eight hours' actual work, their wages being 2.25 liras, or 1s. 10d. per day. The spoons hold 140 kilograms of sand each; the operation of dropping, filling, raising, and emptying occupying one and three-quarter minute; hence the quantity raised by each spoon per hour is 4.9 tons; or by fourteen spoons working simultaneously in the different pits $=68 \cdot 6$ tons, total in three and a half hours $=240$ tons. The comparative cost of dredging therefore works out as follows :- 
(1.) By Manual Labour:--

Liras.

Wages of forty-two men for $3 \frac{1}{2}$ hours' work $=$. . . $\quad 46.20$

Interest and wear and tear on 14,000 liras (the cost of the fourteen barges and tools), at 10 per cent. per annum .\}

Cost of dredging $=\frac{50.90 \text { liras }}{240 \text { tons }}=21 \cdot 2$ cent. $=2 \cdot 04 d$. per ton.

(2.) By Steam-Dredger of the Priestman "B" type of 8 HP.

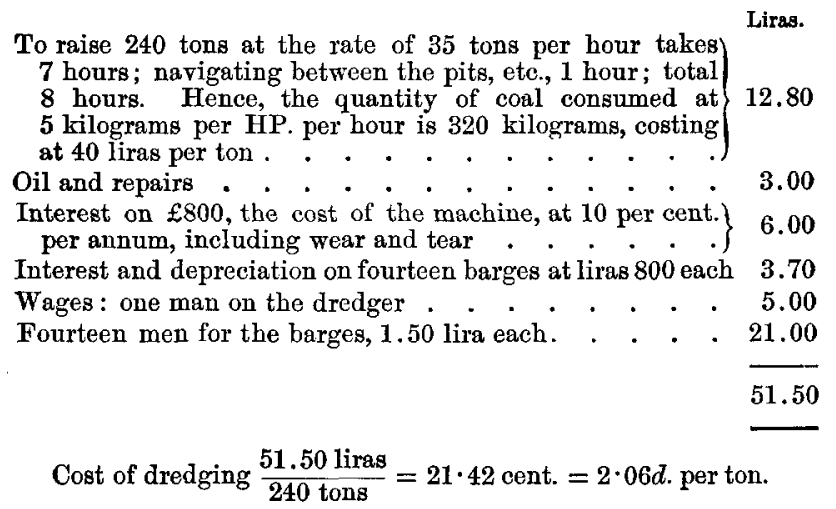

It is thus seen that while the cost is practically the same in both cases, the forty-two men do the work in three and a half hours, whereas the steam-dredger requires eight hours, or more than double the time. A considerable saving could be effected if the sand were discharged by the buckets of the steam-dredger direct into the trucks.

\section{Exports of Marble.}

According to the official statistics annually published by the Carrara Chamber of Commerce, the mean exports of marble in blocks, in slabs, and polished during the last decade to all parts of the world amount to 133,000 tons from Carrara and Massa, to which must be added the exports from Seravezza, 30,000 tons, making a total of 163,000 tons per annum. The maximum was reached in 1887, when the exports were: Carrara, 166,000; Massa, 20,000; and Seravezza, 40,000; total, 226,000 tons, irrespective of the marble used in the district itself. Moreover, the debris is largely employed for masonry and road-metal, and when powdered, 
is used in the manufacture of artificial mineral water, the white marble containing over 90 per cent. of carbonate of lime. The value of the annual exports averages 100 liras, or $£ 4$, per ton, amounting to upwards of $£ 670,000$. At Carrara the Municipal Corporation levies a toll varying, according to quality, from 1 to 5 liras per ton on the output of the quarries, the annual revenue accruing therefrom amounting, on an average, to $£ 12,000$, part of which sum goes towards keeping in repair the marble roads, the cost of maintenance of these being, throughout the district, from $£ 60$ to $£ 100$ per mile.

\section{Marble Railway.}

The total length of the line from the sea to the quarries is $25 \cdot 6$ kilometres (16 miles), including the section from Avenza to Carrara, which forms part of the Mediterranean railway system, but over which the Marble Railway Company has running powers. The length of the Marble Railway proper is therefore, including branches, 20.6 kilometres (13 miles), of which the first or lower section of 7 miles was opened in the year 1873. Owing to financial difficulties, arising out of the onerous terms of the concession imposed by the Carrara Corporation, the second or mountainous section of $6 \frac{1}{2}$ miles was not commenced till 1887, being completed in May, 1890. The loading-stages of the principal quarries (Crestola, Piastre, Canal Bianco, Para, Fantiscritti, Canal Grande, Ravaccione, Colonnata and Gioja), Fig. 2, Plate 11, are situated at altitudes varying from 876 to 1,492 feet, and at comparatively short distances apart, but are separated from each other by steep ridges rising up to 3,000 feet above sealevel. At first sight the idea would naturally suggest itself of running a separate branch up to each quarry from Carrara, following the ancient watercourses now occupied by the bullockcart roads; but this would be impracticable owing to the rapid rise of the ground, necessitating grades up to 15 per cent., on which even a combined adhesion and rack-engine would only push a load equal to its own weight. Rope-traction on inclined planes would have involved placing a stationary engine of $150 \mathrm{HP}$. in each of the nine quarries, which, moreover, are almost destitute of water; and hence the only practicable and adequate alignmentrof the mountainous section, with grades of from 4 to 6 per cent., to be, worked by ordinary adhesion, was that of a series of reverse stations, as illustrated by Fig. 4, Plate 11. 
The grade of 4.5 per cent. is tolerably uniform throughout the ascent of 1,207 feet from Carrara to the summit-level at Ravaccione, Fig. 5, Plate 11. It increases to 5 and 6 per cent. near the Colonnata terminus, and the two safety sidings near Miseglia and Tornone have a grade of 7 per cent. The minimum radius of curvature is 5 chains and the maximum 9 chains, with the exception of one of .50 chains, and the shortest straight length between reverse curves is 11 yards. About 2 miles, or 40 per cent. of the entire length of the mountainous section, is in curves. The works throughout are very heavy, there being fifteen tunnels, with a total length of 2.8 miles, and sixteen bridges and viaducts, while the remainder consists entirely of cuttings and sustaining walls from 16 to 46 feet in depth. This was rendered necessary not only by the nature of the ground and the high cost of land contiguous to the quarries, but by the loose masses of marble debris, which could only be avoided by extensive tunnelling. The tunnels have a cross-section of 39.4 square yards, and pass almost exclusively through the compact marble and limestone strata, which also yielded the material for the bridges and walls, as well as for the packing and ballast of the permanent way. The following was the mean cost of the work:Tunnelling (without lining), $£ 23$ per lineal yard; excavation in cuttings, 4s. per cubic yard; dry masonry, 3s. per cubic yard; rubble masonry, 48. 10d. per cubic yard; and ashlar masonry, 9s. per cubic yard. As many of the blocks are exported direct from the quarries, the line is constructed on the 4 -foot $8 \frac{1}{2}$-inch gauge, with steel rails (Vignoles section), supplied by the Terni Steel Works, weighing 72 lbs. per yard, and $29 \cdot 5$ feet in length. They are fastened with three dogspikes and sole-plate to oak sleepers of $7 \cdot 5$ feet by $5 \cdot 5$ inches by 8 inches, there being ten of these to each rail length. The steel angle (suspended) fish-joints, which are 16 inches long, and weigh $32 \mathrm{lbs}$., make a joint as stiff as the rail itself. The depth of the rail is 13 centimetres; hence its moment of resistance $=0.07 \times 13^{3}=154$ centimetres $(3.31$ inches $)$ and the greatest load it can bear between sleepers, 2.96 feet apart, from centre to centre, taking the tensile strain at $7 \cdot 3$ tons per square inch, is 15.5 English tons. The permanent way is, therefore, not inferior to that of the trunk lines crossing the Alps and Apennines. The maximum load of engines and trucks is 7 metric tons per wheel; hence the greatest strain to which the rail is subjected is $7,000 \times \frac{90}{8} \times 154=510$ kilograms per square eentimetre (3.1 English tons per square inch). The cost of the rails, delivered on the line, was $£ 816$ s. per English ton; that of the 
sleepers, $4 s .9 d$. each, and the total cost of the permanent way, $26 s .4 d$. per lineal yard. The total actual cost of construction (including. land and compensation) of the whole line of 13 miles was $£ 320,000$, which, with $£ 20,000$ of rolling stock, amounts to $£ 26,158$ per mile, exclusive of financial charges and interest. The making of the mountain section occupied two years and a half, the contract beingcarried out by the Venetian Public Works Company of Padua.

The lower section, from the sea to Carrara, is worked by two four-wheeled Krauss tender-engines of 25 tons, and the upper section by two six-wheeled (coupled) Krauss engines of 34 tons when full, the two last named being fitted with Riggenbach airbrakes, the cost, inclusive of duty and carriage, being $£ 1,200$ and $£ 1,600$ respectively. The company owns, for local and through marble traffic, seventy-four four-wheeled trucks; twenty-six of which carry 10 tons, eight carry 15 tons, and forty take a load of 20 tons, and two six-wheeled trucks which serve to transport blocks u $]^{*}$ to 28 and 36 tons respectively. They are fitted with powerful screw-brakes, and are of special construction, their weight being only one-third, and in the case of the six-wheeled trucks one-fourth of the load they carry, the length of the platform varying from 13 to 16.5 feet, the width being 7 to 8 feet. The rigid wheel-base is in all cases 8 feet, so as to enable the trucks to pass the sharpest curves. Blocks of exceptional dimensions for colossal statues or monuments up to 40 tons are carried on two 20-ton trucks, in the centre of which cross-beams are pivoted, with rails laid upon them so as to form a platform; but for blocks exceeding 40 tons special trucks have to be built. The 20-ton trucks were nearly all built by the Bristol Wagon Company, and have given the most satisfactory results; whilst some new ones on the same model have lately been supplied by Messrs. F. Grondona and Co., of Milan, the cost being $£ 130$. They have a short platform which has been found to be of great advantage, whereas the 15-ton (six-wheeled) and the 25-ton (eight-wheeled, on two bogies) through-traffic marble-trucks of the Mediterranean Railway Company, the platforms of which are 23 and 33 feet long, do not answer so well, that of the former being liable to bend at the ends owing to the great overhang, and that of the latter in the centre, from the bogies being too far apart. The 34-ton engines which work the steep gradients have the following leading dimensions:-diameter of the cylinders, 40 centimetres ( $15 \cdot 7$ inches); length of the stroke, 60 centimetres (23.6 inches); diameter of the driving-wheels, 108 centimetres (42.5 inches); pressure in the boiler, $170 \mathrm{lbs}$. per square inch; hence their effective tractive force at half-pressure is 4,860 kilo- 
grams $(10,690 \mathrm{lbs}$.$) , or one-seventh of the weight of the engine.$ Taking the resistance of the train on sharp curves at 10 kilograms per ton, the engine should and does haul, exclusive of its own weight, and under ordinary conditions, $=\frac{4860}{\text { grade per mile }+10}-34$, or, on the different gradients :-

On 3 per cent. gradient 87

$\begin{array}{llll}" 4 & " & " & 63 \\ " 4.5 & " & " & 54 \\ " 5 & " & " & 46 \\ " 6 & " & " & 36\end{array}$

During wet weather, or frost, these loads have to be reduced by 10 per cent. The engine then hauls or pushes on the $4 \cdot 5$ gradient eight empty 20-ton trucks, or a load of 48 tons, at a speed of 2.8 metres per second, the resistance it overcomes being therefore $(48+34) \times(45+10)=4,510$ kilograms, so that the coefficient of adhesion is reduced from one-seventh to $\frac{4,510}{34,000}=$ one-eighth, while the power developed is $\frac{4,510 \times 2 \cdot 8}{75}=168 \mathrm{HP}$. The engine takes down the incline, under favourable conditions, fifteen full trucks, or 390 tons, and covers about 100 kilometres

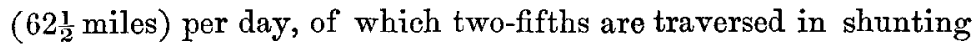
at reverse stations and quarries, the consumption of coal, at 288 . per ton, being about 1 ton per day of ten hours' work.

The working expenditure of the line is considerably increased by the fact of the Company, in order to secure the traffic, being obliged not only to keep a large number of bullocks for conveying the material to the saw-mills, and at the storeyards, but also to work some of the inclined planes. Before the new section was opened, the cost of this, and of cartage by one hundred bullocks, amounted to over $£ 8,000$ per annum, equal to more than 50 per cent. of the entire working expenditure, which represented nearly 90 per cent. of the gross earnings. Since then this item has been reduced to about one-half; but although the rates are remunerative per $s e$, the mean rate being 50 centimes per ton per kilometre ( $7 \frac{1}{2} d$. per ton per mile), including loading and unloading, it is clear that the working expenditure cannot be brought much below 65 per cent., until all the accessible quarries, saw-mills, and storeyards have been connected by branches and sidings, and the cost of working the inclined planes has been reduced. As regards this last desideratum, the Author has recently designed a four-wheeled 
trolley, or rack-engine, to be worked by six men, which will, by a series of pinions, transmit sufficient power to push, besides its own weight and that of the men, two empty trucks up an incline of 15 per cent. The inclines are laid on the ordinary gauge with a raised single central rack of the ladder type, in lengths of 100 metres alternating with short level stages, in order to rest the men. A pinion-wheel, with a powerful screw-brake acting upon it, will serve to retard or arrest the loaded truck on descending the incline, and the trolley will be provided both with a pinion and a slipper brake. The design is an adaptation of a similar but lighter machine, which has been worked for years on an incline of 6 per cent. in a stone quarry near Berne, in Switzerland. The cost of working short inclined planes in this way at Carrara will be about 1 lira per ton, against the present cost of 2 liras per ton, thus effecting a saving of 50 per cent.

A light railway (metre-gauge) of about 5 miles in length has recently been opened from Massa to the sea, while in the Seravezza division, a system of light railways on the same gauge, to be laid alongside the public roads, and to extend also to the sand-pits of Viareggio, has been approved by the Italian Government upon the surveys and designs made by the Author, and the works are now being carried out by the local authorities.

The Paper is accompanied by a tracing from which Plate 11 has been prepared. 


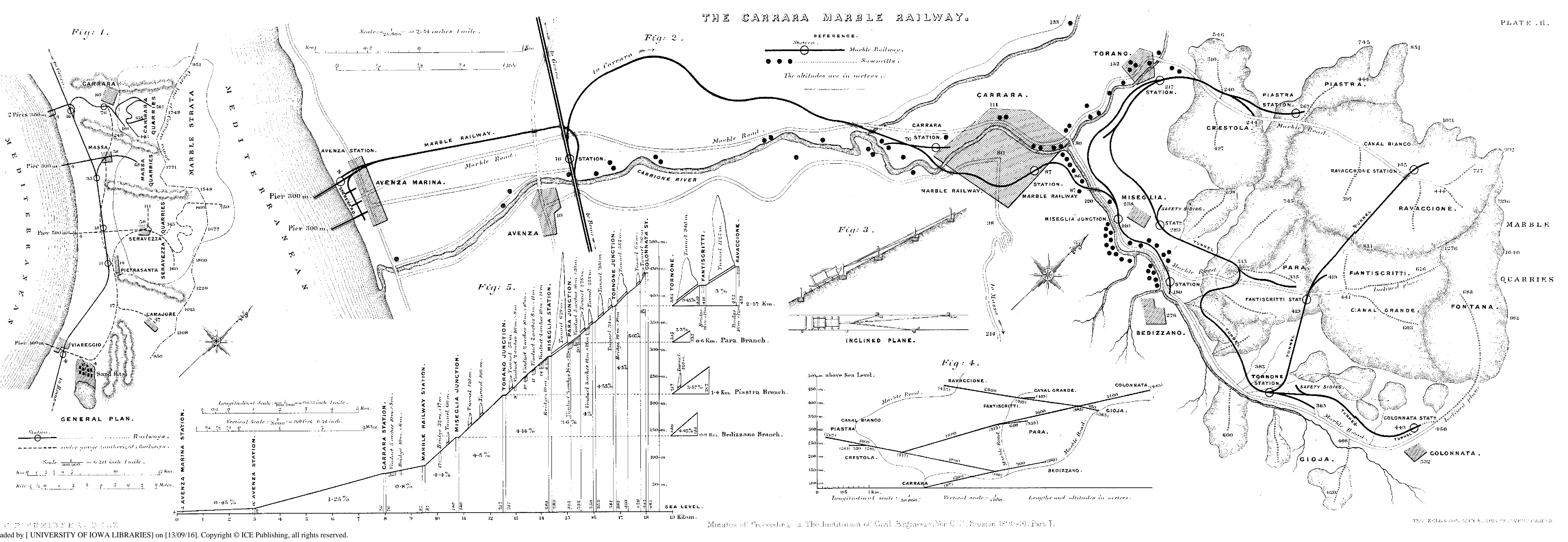

